\title{
Third way departures and 21st-century social democracy: Corbyn vs Macron
}

\begin{abstract}
In the 1990s, European social democracts coalesced around a set of principles often referred to as the third way - characterised by prudent economic governance, a slimmer public sector, 'productive' welfare services and attraction to inward investment. Third way proponents perceived fairness as supporting opportunity rather than redistributing welfare. On the way to the late 2000s, their sense of direction was lost. The final phase, one might argue, ended with the 2008-2009 financial crisis. Henceforth, the challenge for the Left concerned how to define a social democracy with less revenue and limited scope for expanding public services, while reaching out to the so-called left-behinds through better jobs and a renewed sense of common purpose.
\end{abstract}

Jeremy Corbyn and Emmanuel Macron represent two distinctly different attempts at forging a new way forward from the impasse. During Corbyn's tenure as a leader (2015-2020), Labour carved out space by moving leftwards on key economic policies while proffering communitarianism as the antidote to globalised capitalism. Across the English Channel, Macron's new party, La République En Marche, sought to generate a new form of politics that had clear similarities with the centrism of third way social democracy, supplemented by an emphasis on social dialogue and enhanced European integration as a strategy for harnessing globalisation.

Corbynism and Macronism represent two distinct attempts at centre-left renewal, both personalised yet evolving on the back of mass movements. This article summarises the trajectory of both in terms of ideological content and organisational change and asks what lessons they convey about the future of social democracy in the 21 th century. 


\section{Introduction}

To anyone steeped in the history of social democracy, Jeremy Corbyn and Emmanuel Macron might appear as unlikely suspects for comparative analysis. Corbyn is often referred to as a 'Bennite Socialist', if not a fully-fledged Marxist, while Macron has been dubbed 'Margaret Macron' or 'Emmanuel Thatcher' (cf. Gilbert, 2018; Pedder, 2018; Rathgeb \& Wolkenstein, 2017). Corbyn was an unknown Member of Parliament, at best acknowledged as principled in his views, before entering the limelight as the elected leader of the British Labour Party in 2015. Macron, on the other hand, was a 39-year-old former civil servant and investment banker with only a limited foothold in both French politics and the socialist movement when he left the Parti Socialiste (PS) government in 2016 to establish his personalised political party, La République En Marche (LaREM). After landing two straight election losses, and with Labour's further prospects uncertain, Corbyn resigned in late 2019, and few of his closest associates remained in leadership positions. At the time of writing, Macron is three years into his presidential term, with his popularity in decline and his agenda for renewal implemented only sketchily. Furthermore, his electoral base has seen significant shifts from a centre-left/soft-right coalition to a more outright centre-right voting bloc, which has also led to LaREM's policies shifting in a similar direction (Sage, 2020).

These two personalities' precarious status notwithstanding, we will argue that Corbynism and Macronism remain significant as contrasting approaches to the challenges the European Left is facing. Essentially, Corbynism and Macronism represent two distinct pathways out of the ambiguity and uncertainty that has characterised the European Left since the onset of financial crisis towards the end of the 2000s. Thus, they are both, in a sense, products of the era of the third way, where Corbyn is perceived as the antithesis of the New Labour era of Tony Blair, while Macron is widely held to be the French heir to Blair.

If we follow this perspective, Macron sees the third way diagnosis as largely correct but only half-heartedly implemented in France. A reinvigorated Left should therefore hark back to the globalist liberal creed of the 1990s. Cross-class alliances are formed from the centre ground, where entrepreneurship is applauded and individualism encouraged. Jeremy Corbyn's appeal, by contrast, drew on his 
consistent opposition to the New Labour era. Centrism was, in substance, a capitulation to financial capitalism. Blair's Britain was a country of deepening inequality, low-paid service jobs, stigmatised welfare services and political elitism. Just as Corbyn's leadership was framed as the antithesis of Blair's, Corbynism positioned itself as everything the third way was not.

This is also where our analysis sets off. As Jack Shenker (2019) contends, Corbyn himself may be 'the least interesting thing about the phenomenon. Far more important than any individual is the question of what kind of future Corbynism hopes to build'. The radicalisation of Labour under Corbyn took the party to terrains inhabited by radical Left parties, particularly the insurrectional tendency represented by Podemos in Spain and Syriza in Greece. In France, one could argue that the appropriate reference to the rise of Corbyn would be the left-wing maverick Jean-Luc Mélenchon (Cole, 2019, pp. 11-12), who chose to leave PS after the left wing's loss at the Reims convention in 2008. However, it is not the radical challenge to social democracy that is the topic of this chapter. Rather, we seek to explore and compare the emergence of Corbyn and Macron as two distinct and important reference points for the European Left. Our comparison will be directed towards two specific features: their ideological outlooks and programmes for government and the party movements that emerged under their leadership. We seek to tease out a coherent set of principles embedded in each of the two versions of renewal and, in doing so, attempt to answer two important questions: First, what can explain the diverging pathways of the British and French Left following the failure to define a plausible form of austerity socialism? And second, what future trajectories for the European Left might we infer from the pathways charted out by the two parties?

\section{The third way and after}

Third way social democracy was a response to a profound sense of social and ideological crisis within social democratic parties faced with both the political challenges posed by neoliberalism and the Left's own tarnished reputation due to perceived excesses and failed policies in the 1970s and 1980s. The two most prominent cases, Gerhard Schröder in Germany and Tony Blair in Britain, returned their parties to power after a sustained period in opposition -18 years for Labour and 16 years for the Sozialdemokratische Partei Deutschlands (SPD) (Coates \& Lawler, 
2000, p. 26; Wolfrum, 2013). The perception that had developed in the early 1990s was that leaving the political wilderness necessitated some form of break from the past, at least symbolically. In Germany, Schröder dubbed his project the 'New Centre' (Neue Mitte), while Blair, having abandoned the commitment to the nationalisation of industry, rebranded his party as 'New Labour' (cf. Daniels \& McIlroy, 2008; Egle, Ostheim, \& Zohlnhöfer, 2018). The catchphrase of the third way ideas, going back to the latter half of the 1980s, was 'freedom', which legitimised a programmatic strategy of organisational and ideological renewal.

The intellectual gist of the third way was an acceptance of international market forces combined with a sustained commitment to equality of opportunity, leaving the ambitions of extensive redistribution as a relic of the past. The turn towards individual empowerment was recognisable in policies as well as rhetoric. Emphasis on life chances and social inclusion took over where equality had prevailed. third way ideas sought a renewal of the European Left by embracing globalisation and enabling individuals to thrive through state investment in education and key social services. As a class compromise, the third way sought cooperation with the business sector over free trade and fiscal stability while attracting progressive voters in the middle class through social and cultural liberalism. The renewal was framed as 'a principled critique of straightforward neoliberalism' (Crouch, 2013, p. 157), yet of equal importance was the abandonment of the collectivist politics of the industrial era. The ideational struggle over macroeconomic policy had been fought and lost in a drawnout version of the 1970s. After Keynesianism, there seemed to be little the state could or should do in terms of macroeconomic regulation. What remained was a singleminded pursuit of low inflation in support of free trade and openness to investment. Any remaining 'supply-side socialism' would be limited to supporting a competent workforce, effective administration and private sector-driven growth, whose windfall could furnish further investment in public services.

Under these revised terms, as Perry Anderson (1994) has argued, it was unclear how traditional aims of social equality and full employment could, or even should, be fulfilled. Indeed, the modernisers on the centre-left had great difficulty drawing a fixed line between social democratic renewal and a modernised form of social liberalism. A case in point predating the 1990s is François Mitterrand's austerity turn (tournant de la rigueur) only two years into his first term, which gave priority to anti-inflation policies to increase French competitiveness and entailed 
some deregulation of the finance markets and privatisation (Bearce, 2009, pp. 205207). The British 'big bang' of stock exchange liberalisation in the period 1986-1987 was echoed by milder reforms in Scandinavia, deregulating the credit supply of banks and bolstering their role in financial speculation (cf. Dølvik et al., 2014, p. 30). Withdrawing state control to this extent had an intimidating ring to critics who claimed modernisation trumped adherence to core social democratic ideas (cf. Hattersley, 2004). While public ownership of industry could be pragmatically disposed of, it was difficult to reset the belief that the government should regulate, civilise and redistribute where needed.

The third way emerged from a decade of ideological confusion and wide-ranging political change. The fall of the Berlin Wall and the ensuing end of the Cold War accelerated the consensus around free trade. The task for social democracy, one assumed, was to provide the social stability and equal opportunity that neoliberalism could not cater for (Gamble \& Wright, 1999). The thesis of sociologist Anthony Giddens was that a renewed social democracy could be influenced by the Left and Right alike while avoiding the pitfalls of both sides. In an era of globalisation, the case for supporting the individual was as strong as ever. The means for doing so, however, should involve tailored and flexible public services rather than 'one size fits all'. Finally, the third way acknowledged that toughness on crime and a welfare state based on personal responsibility were areas where lessons could be learnt from the Right (Giddens, 1998).

Spanning across these strategic policy statements was the belief that globalisation had transformed the scope for politics. History had reached a point where the liberal philosopher Friedrich von Hayek appeared to be right after all: society had obtained a level of complexity where detailed state planning was no longer possible. What could be done was to offer an even playing field and encourage strong communities. Thus, complexity, as well as individualism, necessitated a break from postwar collectivism.

The 'enabling state' proffered by the third way was not entirely new to social democrats. Swedish prime minister Tage Erlander often referred to the purpose of politics as building an even dance floor that allowed for the people to choose their individual styles of dancing. The assumption that a sufficiently even dance floor could be constructed and sustained was, however, heavily debated at the time and has provoked even more scepticism with the benefit of hindsight (Heffernan, 2001, ch. 1). 
In Britain, the Labour Party was incapable of rectifying the deep social inequalities and unable to handle existential challenges such as climate change. The third way was also a fair-weather creed, capable of allocating opportunities but poorly equipped to deal with a downturn. Founded on dynamic markets and having done away with the tools of Keynesianism, it would meet intellectual and political difficulties when economic conditions became adverse. Where the economy grows, there are better chances of relieving poverty - raising the level of welfare and investing in the public sector, all without increasing taxes beyond the publicly accepted levels. The long decade from the late 1990s provided ideal conditions for this form of gilded social democracy, where a rising tide would lift all boats. But electorally, following the initial rise in popularity, the newfound hegemony had little to offer in the longer run. In its wake followed accusations of betrayal against the 'authentic Left' in the sense of 'Old Labour' or, in the French case, genuine socialism.

\subsection{Downfall and austerity}

The four years from 1998 to 2002 provided a brief occasion of concurrent centre-left governments in Britain, France and Germany. France was the first to falter - as Lionel Jospin and PS, scarred by an unsuccessful presidential campaign against Jacques Chirac in May 2002, went on to lose heavily in the subsequent parliamentary election. The German SPD was the next to fall, as Gerhard Schröder resigned after his coalition government failed to hold onto the majority in the 2005 parliamentary election.

Labour held on until Gordon Brown's defeat in the 2010 general election.

In France, as PS languished in opposition, Jospin's defeat set the terms for an extended debate over ideology and direction which provided fewer solutions than cleavages. Meanwhile, the centre-right government from Union pour un Mouvement Populaire seemed to take up the mantle of the third way in its image. Nicolas Sarkozy rose to prominence from ministerial posts to become president of the Republic from 2007 to 2012 . As president, he sought to emulate and amplify key reformist ideas derived from the third way - such as loosening employment law, reorganising and trimming the public sector and encouraging technological change. The difficulties in staking out a centre-left course showed itself when on the eve of the party's 2008 convention, the failed 2007 presidential candidate, Ségolène Royal, declared social 
democracy was un modèle périmé, an outdated model that had stopped serving its purpose.

We must move forward, not return to the ideas of social democracy or even liberalism! [...] We need a state that changes the balance of power and not, as in the social democratic model, a state which alleviates problems but does not attempt to change the system. I am amazed when I still hear Socialists praising the virtues of social democracy in 2008. (Le Parisien, 2008b, our translation)1

After suffering losses at the convention, however, the left wing, led by Jean-Luc Mélenchon, split to form a new party - Parti de Gauche, which would campaign against both the new PS party platform and the EU's Lisbon Treaty (Le Figaro, 2008). Parti de Gauche, which was modelled on Die Linke in Germany, positioned itself as part of an international movement to the left of social democracy and quickly announced an alliance with the French Communist Party (cf. Le Parisien, 2008a).

Initial signs of a changing fortune for PS first appeared in the 2011 local elections, when it became the largest party. PS continued to benefit from controversies encircling the Sarkozy presidency, and following progress in the local elections, the party obtained an unprecedented majority in the French Senate in November 2011. The following year, victory in the polls secured the first Socialist president since 1995 and only the second in the Fifth Republic. François Hollande's victory was followed by a comfortable parliamentary majority for the centre-left coalition. However, a question remained - whether his accession to power came on the back of popular appeal or merely reflected a weakening of the incumbent president. Hollande's promise to be a 'president normal' - a normal president, as opposed to the scandal-ridden Sarkozy and his harsh austerity policies - mobilised voters in the rural areas and the postindustrial cities in Northern France (TF1News, 2011). Hollande's gravitas on the left was also limited from the outset, as his nomination owed more to Dominique Strauss-Kahn's (the party's preferred candidate) involvement in a sex scandal than enthusiasm and mobilisation. The lack of a coherent vision and strategy became visible early on in Hollande's tenure; tensions developed between the party and the government over the nonconfrontational approach to the EU's fiscal agenda, dominated by a conservative faction led by the

\footnotetext{
1 'Bien sûr qu'il faut aller plus loin, et certainement pas en revenant aux idées de la social-démocratie, et encore moins aux idées libérales! [...] Parce qu’il faut un Etat préventif qui change les rapports de force et non pas, comme dans la social-démocratie, un Etat secouriste qui ne remet pas en cause le système. Quand j'entends certains Socialistes vanter les vertus en 2008 du modèle social-démocrate, je suis stupéfaite, car c'est un modèle périmé' (Le Parisien, 2008b).1
} 
German CDU/CSU. Internal friction increased after significant losses in the 2014 local elections, when Hollande's response was to appoint the social-liberal Manuel Valls as prime minister. The appointment of Valls was regarded by the left wing of the party as a step towards a French type of 'Blairism' (cf. Freyssenet, 2014).

Hollande suffered the lowest popularity rating of any French president, and the 'difference-splitting agenda' of the antiausterity rhetoric, combined with attempts at appeasing the Front National's xenophobia, had little appeal to voters either on the right or on the left (cf. Chrisafis, 2013; Earle, 2017). The following years saw a steep decline in both membership and elected representatives - especially in Northern France, which had been the basis for Hollande's victory (cf. Bruckert, 2016). Hardly anyone was surprised when he declined to run for a second term, as PS was threatened by electoral marginalisation. The challenge not only added LaRem in the centre to Jean-Luc Mélenchon's La France Insoumise on the left but also involved a very real risk of internal disintegration in PS (Billard, 2017). As Alistair Cole (2019) has pointed out, the profound unpopularity of the Hollande government made it impossible to campaign for a defence of its policies. Fleshing out a credible form of renewal turned out to be an equally Herculean task, and the replacement candidate, Benoît Hamon, received the lowest score of any PS candidate since 1969 (Cole, 2019, pp. 43, 60). This prompted the general secretary, Jean-Christophe Cambadélis, to announce that the centre-left coalition that had been formed at the party conference in Épinay in 1971, following the crushing electoral defeat two years earlier, was no longer sustainable. Accordingly, a new PS would have to be built, as the party of Épinay was mort et bien mort (beyond dead) (Baldit, 2017). According to the sociologist Jean-Pierre Le Goffe, 'Hollandism' thus signified the end of the 'Épinay cycle', which had been characterised by combining a Gaullist-style presidential rally with a strong tradition of party organisation and self-sufficiency (Cole, 2019, p. 44; Mihaely, 2017). PS was no longer an aspiring mass party and movement nor was it an efficient electoral machine, and following the election, Hamon left the party to form a new organisation, while several others choose to join Macron and LaRem.

In Britain, the Labour governments of Tony Blair were re-elected in 2001 and again in 2005, albeit with diminishing electoral support. When the financial crisis hit in 2008, there was already a sense of reaching the end of an era. Admittedly, Gordon Brown managed to demonstrate a form of economic leadership in helping to mitigate the crisis from his position as prime minister. Its roots, however, were immediately 
attached to Labour in the eyes of the public. The dominating narrative was merciless in pointing to Blair, Brown and the ideas underpinning their 13 years in government. A profligate government of the Left, it was argued, had opened the public purse precisely when caution was needed. Labour had seen public expenditure spiral out of control in the years leading up to the crash. As a consequence, the government was forced to borrow heavily to compensate for the collapse of the financial sector. As the public deficit increased, so did the public distrust towards what appeared to be a traditional tale of leftist 'tax-and-spend' politics being retold. At the 2010 election, a coalition of the Conservative Party and the Liberal Democrats punctuated the New Labour era and simultaneously ended the lengthy period where Blair and Brown had been the leading political forces in the party.

What followed were five years of attempting to regain ground by atoning for the past and winning the battle of ideas in the new context of public debt, low growth and fractured social cohesion. Ed Miliband succeeded Brown as party leader following the electoral defeat - seeing off his older and more experienced brother, David, through a complex electoral procedure where the support of trade unions and affiliated societies tipped the result in his favour (Dorey \& Denham, 2011). A lengthy period of fleshing out a reformist political programme ensued. Miliband's chief obstacle was the assumption of governing incompetence. Moreover, among his supporters, he was also expected to distance himself from the centrist economic policies and conservative foreign policy of his Labour predecessors, Blair and Brown. He tried to resolve this conundrum through a form of ideological renewal combined with fiscal discipline. Labour under Ed Miliband became a philosophical exercise in how to turn dysfunctional capitalism into social democracy. However, the streams of 'retail policies' that emerged from this process were never united by a coherent governing creed. According to Eunice Goes, Miliband proved incapable of providing 'a credible and coherent alternative to the policy puzzles of the day'. These were 'difficulties that were not unique, [but] part of a bigger trend in social democratic politics' (Goes, 2016, p. 185). Labour was in need of a political programme for an era of low economic growth and limited public means to redress deep social inequality. It was a very different context from what the third way ideas had responded to, and the rationale for renewal was sound enough. But Miliband's Labour was incapable of presenting a plausible alternative. The question that remained, and over which the 
2015 leadership debate was fought, was whether this failure was the result of Labour's radical turn or, on the contrary, reforms had not gone far enough.

\subsection{When the centre cannot hold}

Both the French working class and the British working class were hit hard by the wave of deindustrialisation following the post-Cold War wave of globalisation, which was furthered enhanced by the financial crisis towards the end of the 2000 s. According to Gino Raymond (2017, p. 422), governments across the political spectrum have faced increasingly narrow margins for manoeuvring, and political differences have come to rest on framing and personal appeal rather than opposing visions for social change. This both reflects and is reflected in voting patterns that are less conditioned on class identification. Parties, regardless of their political persuasion, preside over a landscape where 'class differences are occluded by a new dividing line between "in" and "out" and those who are "in" or "out" according to the spaces they inhabit' (Raymond, 2017, p. 420). Charting a path onwards from economic crisis and recession, the principal parties of the Left and Right not only lacked ideological cohesion but also, from a historical perspective, were a diminishing fit with the constituencies they claimed to represent.

Hollande's tenure as president would seem to be a case in point. As Robert Elgie (2018, p. 27) has pointed out, French political parties have traditionally been less institutionalised than parties in many other countries, at least partly because of the impact of the personalised nature of presidential elections on party organisations. As it soon became evident that Hollande's promises 'to halt the ravages of globalisation' by tackling the power of global financial capitalism were hollow (Clift \& McDaniel, 2017, p. 406; Raymond, 2017, p. 422), both his popularity and that of PS suffered. Furthermore, the string of financial scandals that had dogged the Sarkozy presidency found an echo in the tax fraud perpetrated by the budget minister Jérôme Cahuzac and the failed proposals to move Europe away from austerity policies through renegotiating critical elements of the EU settlement. The crisis was further enhanced as substantial tax increases slowed down the economy by impeding household purchasing power, and the tax cuts for businesses did not translate into job growth of any significance. Accordingly, the Hollande government found it 
increasingly difficult to articulate a clear or consistent vision for the economy (Clift \& McDaniel, 2017, p. 408).

Hollande's tenure as president was characterised by fundamentally different contextual features from the Labour leadership of Ed Miliband. Where low productivity and high inequality prevailed as dominant challenges to the British Left, French Socialists were faced with a rather different conundrum: an economy that, in some sense, was too densely regulated, protecting insiders in the labour market and aggravating youth unemployment. The European social dimension lauded by the French Left as the logical alternative to neoliberal globalisation had proved immensely difficult to realise. But Hollande and PS remained committed Europeans to an extent that could not and would not be matched by a Labour Party elite marked by the Eurosceptic turn in public discourse in Britain.

Contextual differences in ideological trajectories and conclusions notwithstanding, there were also remarkable similarities between Hollande and Miliband. Both were framed as intellectual forces for a civic left and a postneoliberal political economy. Both grappled with structural economic problems they were incapable of resolving (albeit only Hollande was in the position to formulate policy with a parliamentary majority on his side). Both were accused of incoherent theoretical reasoning. And both concluded their leadership in dire circumstances: Miliband in electoral defeat (2015) and Hollande as the first president in the Fifth Republic not to stand for re-election (2017) due to the deep mistrust and unpopularity his rule had engendered.

Their demise then generated a transformative turn in both cases. Labour saw the unlikely rise to the leadership of a principled outsider from its socialist fringe Jeremy Corbyn. PS fractured under the internal struggle over policy and strategies for re-election. Emmanuel Macron resigned from the Hollande government in August 2016, directing his energy towards the movement he had helped create four months earlier. Arguably, Macron's choice of founding a new party rather than attempting to rebrand PS from within was a result of circumstances more than ideology. It was the tarnished reputation of PS, coupled with an analysis that it was not possible to reform the party, that led to the founding of En Marche! in April 2016 (cf. Macron, 2017, pp. 27-28). The new movement then served as the vehicle of his candidacy in the presidential election of April/May 2017 and the parliamentary election that followed in June 2017. PS would find itself caught between the pro- 
European, pragmatic-centrist social liberalism of Macron and the more radical, Eurosceptic stance of Mélenchon's La France Insoumise (Clift \& McDaniel, 2017, p. 414; Raymond, 2017, p. 422).

What had been demonstrated by social democrats in Britain as well as France was a failure to develop a plausible economic policy for an age of austerity. Labour Party members opted emphatically for the left-wing veteran Corbyn as Miliband's successor. The choice seemed to signify a turn to authenticity and a more genuine form of socialism. PS, meanwhile, split between two outsider strategies: Hamon's attempt to develop visionary ideas from the bottom up and Valls's proposal for the return to a liberal centre the party had briefly occupied two decades earlier. Macron's essential novelty lay in the movement he engendered. On this aspect, there were obvious similarities between the scruffy Old Left veteran Corbyn and the slick centrist moderniser Macron. While they addressed third way social democracy from opposite sides, both attracted a mass following the Left had craved for.

\section{Two departures: Corbynism vs Macronism}

Corbyn and Macron emerged in parallel, and both represented a sense of novelty in their approach to organisation. More precisely, novelty resided in a form of movement politics, drawing heavily on traditions and tropes from street-level mobilisation outside the bounds of political parties. But at the roots of the "movement turn' was an attempt to rethink the ideological predicaments of the Left.

\subsection{Corbyn's Labour: An ideological turn}

In Britain, there were widely different views as to what constituted Corbynism as a set of ideas. A facile interpretation of Labour under Corbyn's leadership (2015-2020) is that there was very little that was new. On the contrary, nostalgia was the prevailing driver behind policies and mobilisation alike. Just as social democratic ideologues have harked back to the postwar golden era, this more distinctly socialist project did the same. In the British context, nostalgia directs the attention to the collectivist reformism of Clement Attlee's 1945-1951 government. Where postwar Labour prepared the ground for the mixed economy and the welfare state, Corbyn sought to reinstall the very same aspects through the renationalisation of key services, up-scaled 
welfare spending and redistributive taxation. The pillars dismantled by the neoliberal hegemony of the last four decades would thus be restored.

There is much to this narrative of nostalgia, but it needs a corollary.

Corbynism requires a certain reading of the past and a reassessment of how that past could provide operative advice to the current era. A dominant interpretation of Corbyn's persona is that he was socialised politically by the left-wing internationalism of the 1970s and 1980s and that this has remained prevalent in his politics (Davis \& McWilliam, 2018, p. 3). A key influence throughout the early years was Tony Benn, the Labour Member of Parliament whose sustained attack on inequality was combined with a strong emphasis on industrial democracy. Benn's overarching diagnosis pinned Britain's productivity problem on the dominance of finance capitalism, which discriminated against the priorities of industry. What was needed was a form of socialist self-sufficiency within the borders of the nation state (Benn, 1980).

Some specific challenges depicted by Benn have clearly resurfaced in the present era. One concerns the predominance of international finance. Today, its threat resurfaces in large-scale tax evasion and the exploitation of labour in the 'gig economy'. Neoliberalism has only served to aggravate this problem, eroding the remaining industrial base and grounding the growth there is on private debt and financial services. Thus, amending the economic model in the UK and ensuring a larger and more stable base of revenue walk hand in hand. The answer must be, in part, much more forceful regulation and taxation, presently directed towards tech giants such as Facebook and Google. These companies also illustrate some of the structural issues related to international capitalism. Without fixed working hours, stable location and formal representation against the employer, little is left of the shop-floor mentality and trade unionism on which the Left once depended.

It should be acknowledged, however, that Corbynism as an outlook and strategy represents an extensive widening of the agenda from the 1980s radicalism that Corbyn himself is rooted in. The Labour leader appeared, to some extent, as a floating signifier to which desired policies and values can be attached at will by the broader movement around him (Bassett, 2019, pp. 37-38). Since the 1980s, it has been a common assumption in Britain 'that the Right had won the economic argument, but the Left had won the social and cultural argument' (Davis \& 
McWilliam, 2018, p. 2). Corbynism challenged that conclusion by throwing fundamental economic reform into an agenda shared with cultural liberals.

The discussion on what 'actually existing Corbynism' should entail accelerated in the wake of a surprising surge in electoral support at the 2017 general election. The Labour Party's manifesto, entitled For the Many, Not the Few, was coined the real winner of the electoral campaign. In ideological terms, it was far from the sectarian Left Corbyn was habitually associated with. Limited to a general criticism of inequality, it presented itself as 'a traditional social-democratic prospectus, defending the substantive achievements of the Blair/Brown years' (Stafford \& Sutcliffe-Braithwaite, 2017, p. 6). Thus, the democratisation and national control suggested by Corbyn's roots in the early 1980s were hardly discernible. While radical in its general direction and rejection of fiscal prudence, the actual policies fell short of providing a consistent and coherent postcapitalist alternative. Rather, as Owen Worth (2019, p. 487) has pointed out, it was a moderately reformist response to the politics of austerity. In terms of ideological tone and emphasis, Labour of 2017 surprisingly seemed more on par with the technocratic, modernising governments of Harold Wilson in the 1960s than the mythologised 1945 government of Clement Attlee (Hannah, 2018, pp. 234-235). Renationalisation of industry focused on train service - which, alongside the proposed abolition of tuition fees, was a vote winner among the middle classes and, particularly, the young. Overall, while the party image was undergoing a profound transformation, the policy offer was characterised by remarkable continuity, which was affected to some extent by the brief and chaotic nature of the Corbyn leadership leading up to the 2017 election (Manwaring \& Smith, 2019).

Labour's dominant ideas were further transformed in the succeeding years. The centre of policy development largely rested with the shadow chancellor, John McDonnell, rather than with Corbyn. The McDonnell agenda involved more extensive nationalisation - including electricity, water, postal services and, controversially, the broadband infrastructure of British Telecom. While these proposals seemed grounded in conventional collectivism, there was more nuance to McDonnell's policy development, which sought to establish a renewed balance between workers, consumers and the state. 
The order it seeks to create is not an end to markets as such but the political re-embedding of workers, communities and consumers within the accumulation process, where such conditions will be enabled by the state. Unlike in the long 1970s, Labour's strategic options are limited by the impact of neoliberalism, particularly in regard to the strengths of the workers' movements. Yet, also unlike the 1970s, Keynesian economics in some form is today politically tenable. (Bassett, 2019, p. 44)

Reformers of the party's outlook had their work cut out. One of their chief challenges was the fact that, as Wright (2018) points out, British social democracy had paid little attention to state institutions and democratic representation beyond the obvious: 'It was simply assumed that the state was the instrument of its purposes and that political democracy would put this instrument into its hands' (p. 249). In this sense, Corbynism, as of 2019, went further in challenging the basic structures of the British state. Nationalisation and strategic state procurement policies sought to channel investment towards regions and sectors suffering from decay in the shadow of Britain's financial sector, which were concentrated in the South East (Hannah, 2018, p. 218). Aims for industrial democracy were visible through the inclusive ownership funds, which would require companies with over 250 employees to make an annual transfer of at least 1 percent of its ownership to a fund managed by workers with rights equal to shareholders (Bassett, 2019, p. 43). Co-ops and mutualisation had obtained much more attention as alternative strategies for economic development and democratisation, with the Labour-dominated Preston city council as a perceived model to emulate. Finally, Labour's economic policy involved an extensive focus on technological change, automatisation and artificial intelligence, as well as structural changes in the labour market. These changes would require other forms of social security than the postwar welfare state; McDonnell even endorsed trials of basic income as part of Labour's new agenda (Guinan \& Hanna, 2018; Volpicelli, 2019).

With hindsight, the development of numerous parallel strands of policy entailed the risk of overburdening; a coherent narrative and a credible economic strategy would be essential criteria if Labour were to gain power in a subsequent election. With fresh and popular ideas presented en masse, Corbynism post-2017 had looked like a winning formula (Goodwin, 2018). However, when the opportunity arose, it was not to be. At the December 2019 election, Labour was reduced to 32,1 percent and returned its lowest number of parliamentary seats since 1935 . While the moving left on economic issues seems to have captured something of a zeitgeist, Labour has failed to link the individual policies to a coherent and believable narrative. 
Rather, as some have criticised, it came across as an attempt to cram a 25 -year plan into a 5-year programme. Furthermore, rather than following Roy Jenkins's dictum of being 'radical in the context of the moment' (Jenkins, 1952, p. 90), the 2019 manifesto became linked with what was regarded as outdated policies of the past.

\section{Organisational reform}

$[\mathrm{C}]$ hanging the incentives for partisan support in order to attract new participants can have consequences for parties. It can shift the locus of representational authority in the party and affect the type of organisational resources the party can draw on ... Moving to an organisational model of expanded and more open affiliation is a delicate balancing act in which parties are moving with the tide of individualisation and fragmentation of party support yet are bound by party traditions and culture. (Garland, 2017, p. 68)

Ideological renewal in Labour went hand in hand with organisational change. Reforms perpetrated under Corbyn's predecessor, Ed Miliband, extended the franchise for the leadership selection to all members of the party on a one member, one vote basis (Garland, 2017, p. 70). Moreover, registered supporters paying a minuscule fee were also allowed to take part. What followed in the course of the campaign in 2015 to select Miliband's successor was mass mobilisation leading to a sharp increase in the party's membership base. The increase served largely in Corbyn's favour; indeed, much of what made Labour Europe's largest party in members arose in support of his candidacy (Whiteley, Poletti, Webb, \& Bale, 2019).

At the roots of this development were at least two distinct strands. Veterans on the left, such as Corbyn himself, had regained relevance through social movements focused on opposing military expansion - such as the Stop the War Coalition, which played a pivotal role in the protests against the 2003 Iraq invasion. To these veterans were added youth activists mobilised by war and unrest abroad and economic decline at home. Movements such as UK Uncut and Occupy arose in the wake of austerity, housing crises and other sources of injustice. They were further nurtured by the perception that the Labour Left had proved organizationally incapable of helping the party recover from defeat (Hannah, 2018, p. 218).

Momentum was designed as a movement within the party to sustain the legacy of Corbyn's 2015 campaign. One year later, Momentum activists helped Corbyn maintain leadership with a strengthened mandate following a challenge from Corbyn's enemies in the parliamentary Labour Party. The precise nature of Momentum was ambiguous from the very start. Activists mobilised by the rise of 
Corbyn may have wanted egalitarian structures and democratic workshops. Others saw in Momentum an opportunity for intraparty manoeuvring, returning to sectarian struggles known from the party's past (Bassett, 2019, pp. 40-41). While Momentum describes itself as a 'people-powered movement' (Dennis, 2020, p. 97), there is little evidence that the organisation fulfils this vision, at least at the national level. Rather, as James Dennis (2020, p. 108) has pointed out, its members are instructed to undertake tasks at the direction of the leadership, often with electoral goals in mind to secure candidates handpicked by the national leadership. Possibly, the most important change brought by Momentum is rather its use of social media to orchestrate mass membership participation through controlled interactivity. While this has proven effective in supporting electoral campaigning, it would seem at odds with the idea of a people-powered movement.

What were the consequences of an expanding party membership base? Susan Scarrow, in a study of changing membership strategies of German parties, refers to 'multi-speed affiliation options' as a possible strategy for enhancing party democracy. In response to the increasing detachment between parties and people, she argues that 'such adaptations could help strengthen parties standing as organisations that are simultaneously representative and democratic' (Scarrow, 2019, p. 178; emphasis in the original). The assertion arguably holds particularly for the Left - given their origins as mass parties, deriving their legitimacy from representing the working class as organised in parties and through trade unions (Moschonas, 2002, p. 22). Whereas the relationship between membership and trade union influence has been a recurrent topic of tension, both have agreed on the need for organisational rigour and hierarchy. Multispeed membership represents a potential threat to this sacralised view of the internal party organisation. What if, in the attempt to attract and absorb grassroots input, social democratic parties tangle supporters, members and delegates in a pool of human resources? In her critical comment on the deformalisation of membership in Labour, Garland (2017) points precisely to this challenge: 'Multi-speed parties not only need to balance open structures with party traditions but also accept that this opening of structures comes with a more fluid support base' (p. 73).

\subsection{Macronism: Beyond Left and Right?}


Macron's entrance to presidential politics in 2016 bore some clear resemblances to the François Mitterrand's presidential style, however with one clear exception: where PS in the post-Épinay era had also emphasised the mass party even within the highly personalised style of French presidential politics, Macron positioned himself as independent of any party structure. Furthermore, his political platform was based on propositions tested in focus groups and ideas collected on the internet rather than a party organisation (Cole, 2019, p. 62).

For Macron, the main schism in modern politics was not Right vs Left, but progressives vs conservatives. As has been pointed out by Alistair Cole, he thus had a clear ambition to 'sweep aside the old party system of Left and Right', which he regarded as being based on 'outdated cleavages' (Cole, 2019, p. 62). Rather, as Raymond (2017, p. 417) has pointed out, Macron tended to see the traditional labels of Left and Right as a superficial gloss over what he saw as the real dividing lines: the challenge of globalisation, the relationship with the EU, the process of rethinking productivity, the reimagination of the national community and secularism (laïcité) faced with religious dogma. In this narrative, he was the liberal, pro-European candidate defending the middle ground against the extremes. As we have seen, the appeal of this message was enhanced by the appointment of the left-wing Hamon as the PS candidate, as it moved the more centrist voters on the left towards LaRem and Macron. It was mirrored by a similar change to his right, after François Fillon beat the more moderate Alain Juppé for the Les Républicains nomination. Furthermore, with Marine Le Pen and Front National (in 2018 renamed Rassemblement National) coming second in the first electoral round, the French electorate was left with the choice of voting for the unknown element, Macron, rather than seeing the neofascism of Le Pen prevail.

According to Robert Elgie (2018, p. 25), LaRem can thus be interpreted as a combination of the moderate Right and moderate Left, primarily opposed by the radical Right and the radical Left within the current party system. As such, France under Macron represents tripartition in a new form. One side of the opposition is an extreme, or rather antisystem, Left rooted in a common set of antiausterity economic values and cultural/universalist values. On the other side resides a radical Right that is split on economic policies but united around resisting cultural/universalist values. And in the middle is a combination of moderate Left and moderate Right voters, irreconcilably opposed to the antisystem Left in terms of economic policy and the 
extreme Right on cultural/universalist values (Elgie, 2018, p. 26). Nick Hewitt (2017) has therefore claimed that at least the early stage Macronism was 'an amalgam of the Right of the PS and the liberal wing of Les Républicains, with some non-aligned specialists lending a hand as well' (p. 380).

Macron's initial programme for government borrowed heavily from both the Right and the Left. On the one hand, he proposed some deregulation of business and reduction of the state. On the other hand, he put forward a strong defence for social security. These two pillars of Macron's project pointed to a political movement cross-cutting the traditional left-right divide and a concept of political 'renovation' that would 'moralise' French politics through institutional reforms to sustain the overall structures of the Fifth Republic (Evans \& Ivaldi, 2018, p. 152). This included introducing proportional representation, albeit only for a limited number of parliamentary seats, and anticorruption measures such as limiting presidential re-election to three terms and a clean criminal record as a prerequisite for standing as a candidate in French elections (Evans \& Ivaldi, 2018, p. 152). The need for reform was especially rooted in the recent European and French experiences of illiberal populism and extremism, where Macron felt that the only way to save and strengthen liberal democracy was through economic and social reforms (Macron, 2017, pp. 2829).

Macron's social and economic policies combined a promise of expanding welfare provisions and social protection with middle-class tax cuts. In monetary terms, a $€ 50$ billion five-year investment plan prioritising education and vocational training was offset by measures of labour market flexibility, proposals for $€ 60$ billion cuts to public spending and a reduction of 120,000 jobs in the public sector. LaRem's environmental policies, however, were - in contrast to the emphasis on radical green policies put forward by Hamon and Mélenchon - largely built on the existing policies of the Hollande administration (Evans \& Ivaldi, 2018, p. 159). With regard to cultural policies, by contrast, Macron doubled up with radical candidates on the left (Evans \& Ivaldi, 2018, pp. 156, 158). Macron emphasised a universalistic view of identity and immigration, putting a clear distance between LaRem and the parties on the Right, especially the Front National. The party platform outlined a proimmigration stance with regard to asylum seekers and refugees and endorsed minority rights while proposing a managerial approach in regard to economic migrants. 
The most important difference with regard to policies is to be found in the approach to European politics. Macron advocated the rebuilding of 'the European dream' through increased integration and cooperation on fiscal, environmental and social issues while strengthening the EU's external borders. In his programme for the forthcoming presidential election, which was first presented at a mass rally in Paris on 12 October 2016, he proposed setting up three shields to protect the individual against the forces of the globalised markets: a security shield, an active social shield and a European shield (Baïetto, Godon, \& Brunn, 2016). The EU was thus to form an outer shield, protecting its inhabitants from the debilitating effects of the globalised economy.

It is, however, questionable to what extent the actual content of Macron's European policies differs from that of Hollande. As Clift and McDaniel (2017, p. 407) have pointed out, Hollande's strategic failure had been unrealistically relying upon significant European reform to enhance France's discretionary fiscal capability. But most of the initial reforms at the EU level that Macron pushed for early on had been put on the table by Hollande, including a Eurozone finance minister and shared budgets (Clift \& McDaniel, 2017, p. 413). Macron's close relationship with German chancellor Angela Merkel, however, is decidedly different. A case in point would be the joint Franco-German proposal for a $€ 500$ billion post-COVID-19 recovery fund, for the first time allowing the European Commission to borrow from financial markets rather than the individual states. As Sylvi Kauffmann (2020) has pointed out, the proposal is in line with long-held French aspirations for the EU but represents a major ideological shift for Germany, which has resisted the idea of a 'transfer union' where the wealthier states pay for the less well-managed member states. Unlike the response to the financial crisis at the end of the 2000s, which put stringent conditions to any assistance provided, the new proposal is based on grants rather than loans and the money will be reimbursed by the EU and not the individual country that benefits (Kauffmann, 2020). While at the time of writing it is still unclear what the EU's response to the pandemic will be, Macron has thus been able to get his German counterpart on board to stake out a new geopolitical course. If successful, it might very well be the starting point for a more assertive Europe in world politics, in line with Macron's vision for a European shield. 


\section{Movement politics}

A common criticism of Macron from the Left, increasingly prominent as the gilets jaunes protests increased throughout 2018, is that his political outlook is only a little more than a rerun of Sarkozy's - with more emphasis on egalitarianism, mobilising the young middle class while ignoring the working class. For example, as Cole (2019) has pointed out, what began as a protest against a tax increase soon came to mobilise 'mainly rural and small-town people surviving just above the poverty line who felt themselves the target of a distant central government and a cold, rather arrogant, president' (x). While Macron is equally likely to dispute comparisons to Sarkozy as he would references to Blair and Schröder, the starting point for his political vision was undoubtedly derived from a similar perception of a societal and ideological crisis for the centre-left in the 2010s, as that of Britain and Germany in the 1990s. His move towards movement politics was a quick and expedient way to compensate for the absence of institutional party support from within PS. LaRem was thus not intended as a democratic and horizontal membership-based organisation, but rather as an activist base to be mobilised for the benefit of supporting Macron. As such, it bears some resemblance to the role Momentum played for Corbyn, as we have described above.

The trajectory towards the forming of LaRem is instructive. The starting point of the new movement was Les Jeunes avec Macron (JAM), a splinter group from the PS youth organisation Mouvement des Jeunes Socialistes (MSJ) that was announced in June 2015. While initially claiming to be independent of Macron, the leadership of the new group, who came from the centre-right of the Mouvement des Jeunes Socialistes, was close to his political adviser, Stéphane Séjourné, and several JAM members became elected representatives for LaRem after the 2017 election (Boudet, 2018). Furthermore, as the launch of the new movement commanded much media attention amidst speculations of Macron running for president, JAM became a platform for his ideas to be discussed while he formally remained as a minister in the Hollande government. In March 2018, JAM was designated as LaRem's youth movement. Like its parent organisation, the only membership requirement is to sign up through a webpage, and according to JAM, its rank had risen to 25,000 by March 2018 (L'Express, 2018). Unlike LaRem, however, the JAM constitution leaves 
the veto power over major decisions to the four founders of the organisation (L’Express, 2018).

A month before launching LaRem on April 6th, 2016, Macron also founded $L a$ Gauche Libre (the Free Left) as an independent, progressive think tank whose stated aim was to unite 'all young people who support progressive, socialist and more general leftist ideas' (Journal Officiel, 2016, p. 91). At this point, the lack of resistance to Macron's increasingly public overtures about starting a new party within the PS also lays claim to an interpretation where Macron was not seen as an adversary but rather as a satellite of the French socialist movement (cf. Salvi, 2018).

At the launch, Macron declared that LaRem should not be a gathering of individuals, but of committed people who share basic values and a will to move forward based on these values. The movement would accept members from other parties and would not impose any fees, and the party programme was to be developed through talking to 100,000 people in a door-to-door action. The opinions gathered would constitute a 'shared diagnosis' of the hopes, fears and expectations of the French people, which would then be handed over to a committee made up of 200 experts who would put the actual programme together (Barbarit, 2016; Raulin, 2016). In the end, however, only about a quarter of the questionnaires were completed, and the processing was left to an external consulting firm, Proxem, to carry out semantic analysis (Noyon, 2016).

While this way of doing politics certainly bears a resemblance to the spin doctoring of New Labour and Clinton's New Democrats, we will argue that LaRem's focus on the mediatised charisma of Macron's leadership, combined with movement politics as a basis, points in a somewhat different direction and might even be seen as closer to Corbyn and the British Labour Party's approach. As Raymond (2017, p. 425) has pointed out, Macron became the figure who not only personified progress beyond old political divides but also embodied 'the ethos of a movement that was nothing if not the promise of change'. This was particularly appealing to a demographic whose cultural frame of reference was global rather than national, and Macron regarded his large majority, which was more due to the logic of the French electoral system, as a full endorsement of his programme and, early on, pressed through with several far-reaching and controversial economic reforms aimed at devolving the power of the state to the market (Royal, 2020, p. 104). However, it did little to respond to the demands of left-behind working-class voters, especially in the 
postindustrial north, that had abandoned PS after the 2012 election and was to become an important part in the gilets jaunes protests (Royal, 2020, pp. 111-112).

\section{Learning from two distinct pathways}

Following the 2008-2009 financial crisis and the period of austerity that ensued, the challenge for the Left concerned how to define a social democracy with less revenue and less scope for an expanding public sector. Corbynism and Macronism represent two distinctly different attempts at forging a new way forward from the impasse. Their trajectories lend themselves to an explanatory typology where we can link the characteristics of each type causally to explain the outcome (Elman, 2009, p. 122). Both set off from similar grievances - relating to the detachment of a political elite from the grassroots that social democracy, perhaps more than any other party family, was formed to represent. This accusation of elitism and technocracy opened the door for a challenge along populist lines - one that would seek to rebuild relations with the base, strengthen the participatory element in the party and redirect references to an elite towards higher social echelons exploiting the system. With Corbyn, the trope, in this regard, was a very familiar one to the Left: the agents of international capitalism, with a particular focus on its financialised elements (Bolton \& Pitts, 2018). Big capital was less of an enemy to Macron for rather obvious reasons, given his past. Where the ideological rejuvenation of LaRem clearly matched Labour's, Labour under Corbyn was in the development of a narrative of cross-class community to counter the supposedly regressive nativism of the far right and the antiglobalisation movement.

To chart a path, some sense of a roadmap is required. In this respect, the French and British Left had different historical experiences to fall back upon. In France, the Mitterrand era, for all its contradictions, would be an obvious reference point for anyone in search of virtues of the Left. Working selectively, essential markers would be social cohesion, the European cause and democratic renewal similar to Mitterrand's 1982 reform towards regionalisation of the hitherto centralised state. In economic policy, meanwhile, the Mitterrand legacy was ambiguous to say the least, given the turnaround from his originally radical position and the transient pattern of ideological factions within PS during his presidency. 
Where the French Left would look to Mitterrand as the obvious reference across seven decades of postwar politics, with Labour, the menu to select from was wider. The 1964-1970 Wilson government, renowned for social liberalism and economic modernisation, was one alternative foregone, despite what was to emerge in the election manifesto of 2017. To Corbyn personally, his own coming-of-age in the 1970s might have served as an inspiration for present-day policy development, but to the broader movement around him, the quintessential reference point was the Attlee government from 1945. Attlee had set the stage for the postwar consensus on Keynesian economic policy and universal welfare-state institutions, a consensus that would only be gradually dismantled in the 1980s. Where Labour under Blair and Brown had been cautious in returning to postwar approaches to welfare and planning, the appetite for returning to past virtues was considerable within the broader labour movement. It counted in Corbyn's favour as well that he had been consistent in his opposition to the foreign policy adventures and militarism that scarred Blair's legacy as prime minister. This, therefore, was the source of Corbyn and Corbynism arriving on the scene with a 'first-mover' advantage.

\section{Table 1 about here}

Ultimately, Labour's policy offer under Corbyn was unable to persuade British voters, with the 2019 parliamentary election marking the final demise of his leadership of the party. Whether Marcon is allowed to sustain his movement as a personal venture will be confirmed by the 2022 presidential election. Since the 2017 election, as LaRem's reform policies have increasingly run into fierce opposition from both the organised Left and the gilets jaunes movement, Macron's electoral base has gradually shifted towards the centre-right. In the 2019 European election, LaRem lost about a quarter of the left-wing supporters that had voted for the party two years earlier while gaining more or less an equal number of centre-right voters (cf. Sage, 2020). As the electoral future of the party is thus linked to keeping these voters, Macronism will likely continue to move towards the preferences of these new voters. However, despite the instability of ideological currents in French politics in recent years, the predominant cleavage at the electoral level in the 2017 elections was precisely the open vs closed or liberal vs conservative cleavage which Macron sought to benefit from, pitting his candidature against that of Marine Le Pen (cf. Raymond, 2017). 
Corbynism and Macronism both emerged on the back of mass movements aiming towards more egalitarian and informal organisational structures. In an era of declining parties in Europe, this specific feature is likely to leave a lasting imprint beyond the legacy of the leader. Perhaps the most important element of both trajectories, therefore, is not what divides them but what they share. Fundamentally, both Corbyn and Macron subscribe to a form of movement politics that has been absent from social democratic politics in recent decades. In their approach to breaking from old hierarchies and installing a more participatory ethos, both have managed to mobilise people who were previously disengaged from the politics of the Left altogether. However, there are lingering questions to what extent Momentum and LaRem have been able to fulfil their stated purpose beyond centralised electoral mobilisation and controlled interactivity. Furthermore, neither movement has shown much effort towards democratising decision-making or acting as a countervailing power to the central party structures.

Thus, whereas the emphasis on movement politics raises new and enticing opportunities, it also puts contradictions on display. Labour and LaRem have yet to prove the viability of alternative governing structures, less institutionalised rules and a more horizontal democracy as befits a social movement. Whether diversity and enhanced participation must clash with the principle of hierarchy remains to be seen. Can multispeed participation and porous borders between activists and supporters be sustained in the long run? Resolving this conundrum will prove essential to the viability of both as credible forces in the space between conventional parties and social movements that they presently inhabit.

Both parties also represent some novelty in their analyses of changes to working life and in seeking to update what empowerment should entail in a globalised world, but both are also contradictory, if not confused, in defining the boundaries of their project. To Macron, the challenge is largely one of adding substance to spin concerning the cross-class community to which he has sought to appeal. The intellectual challenge appears more complicated with regard to Corbynism, where it remains unclear where the borders of the good community should be drawn and how citizenship should be defined in the 21 st century (cf. Schattle, 2018). Labour party's profound ambiguity over Britain's departure from the EU only illustrates this too well. What position should be accorded to migrants, who are lauded as fellow workers and valued for their contribution to Britain yet also scapegoated as the cannon fodder 
of neoliberalism (Akehurst, 2019)? A related question concerns whether social democrats should assume Europe can be a shelter against international market forces or whether it is seen as adding to the pain and impotence inflicted by them. Where the latter argument gets the upper hand, 'social democracy increasingly finds itself fighting a rearguard action to retain issues at a national level' - a strategy that could easily turn out to be electorally and economically counterproductive, a Bennite strategy 40 years downstream (Crouch, 2013, pp. 166-167).

\section{Conclusion}

Social democracy, according to Keating and McCrone (2013, pp. 2-3), is

a political philosophy seeking to reconcile market capitalism with social responsibility; a political tradition, a set of intuitive ideas about fairness and equality ... a way of governing which systematically seeks to include the needs of the deprived and to emphasise the public domain.

From within these boundaries, the Left in Britain and France has been subject to several transformations in both ideological terms and organisational terms. The fundamental debate occurring on the left at this specific point in time is certainly not unique. Labour 'has been debating since its foundation whether equality or community is the core concept of socialism' (Goes, 2016, p. 13), and a similar observation could certainly be drawn about the French Left. But the extent of transition in recent years has been particularly dramatic. Following the brief period of hefty reorientation, Corbynism and Macronism have taken the prime position in both parties. This also suggests that the gist of both will be sustained, even without the specific labels derived from their leadership.

Both Corbyn and Macron should be understood against the backdrop that they defined themselves against, which also goes a long way in deciding what the future will hold. Macron's 2017 victory was explicitly centrist - with 68 of its new parliamentary members previously associated with the PS, 20 with the Union of Democrats and Independents, and 10 with Les Républicains. Furthermore, most of the members from Hamon's Nouvelle Gauche group voted for the government or abstained in the confidence vote. Unlike Mélenchon's La France Insoumise, the new PS leadership has chosen a position of autonomie constructive or the ni Macron ni Mélenchon line vis-à-vis Macron, supporting the new president on certain issues but 
retaining a critical distance or objecting to proposals such as reduction in wealth taxes and reforms towards a flexible labour market. PS's social-liberal Right tends to see LaRem as offering a more attractive home and path to power, exemplified by Valls's decision to sit with the LaRem in the Parliament, whereas the Left argues for a more radical break from the Hollande line. The split is reflected in the parliamentary delegation, where slightly more than a third are 'Macron compatible'. As we have mentioned above, however, as the voting bloc supporting LaRem has shifted towards the centre-right, so has its policies. And in light of this development, a very real question remains on whether the highly mediatised charisma of Macron's leadership is enough to replace the dynamic for change once provided by traditional partisan politics. Furthermore, Macron's EU policies have run into difficulties, as Brexit has sucked a lot of the oxygen out of Brussels, while the political situation, as Germany prepares to transition from the era of Angela Merkel, makes it difficult to engage in new initiatives.

If the future is uncertain for Macronism, it is equally so for Corbynism. The failure of the 2019 election renewed the calls for moving towards the centre on both social policy and economic policy. Keir Starmer, Corbyn's elected successor, entered his position keeping different factions at bay and all opportunities open. He was empowered by a party organisation with immense human resources but faced with a swathe of internal problems to resolve. The most evident one being related to anti-Semitism. A more structural challenge for the years ahead concerns how to encourage party democracy without facilitating factionalism or yielding too much power to outside groups such as Momentum.

In light of all this, what lessons can be drawn for social democrats from these two attempts at reinvigorating French and British politics? As we have argued, Corbynism and Macronism represent two different strategies for harnessing globalisation towards social good, but both have fallen short in precisely this regard. Corbyn emphasised communitarianism and social justice but lacked a vision that extended beyond the nation state, oddly enough for a political leader who has at times seemed more comfortable discussing the Middle East or Latin America than the details of domestic policy. Brexit became a predicament for Corbynism in terms of electoral strategy and reflected a clash of principles, pitting Bennite self-sufficiency against international solidarity. The resulting policy offer was half-baked and much less potent than what Corbynism had offered at the time of leadership change. 
Without a coherent strategy for neither the reversal nor the completion of Brexit, Labour was caught on the back foot. Thus, the very management of economics and migration across borders remained underdeveloped (cf. Bishop \& Payne, 2019). In fact, it could be argued Corbyn even lacked an understanding of how this would apply to the whole of the United Kingdom, as signified by Labour's wavering over a strategy for Scotland being within or outside the UK.

Similarly, Macron's proposal for a European shield, while providing the muscles necessary to stand up to globalised capitalism, lacks the understanding of what is necessary to create a 'bounded world' of people committed to dividing, exchanging and sharing social goods. This essential process of fostering and maintaining social cohesion has been described by the Italian political scientist Maurizio Ferrera as internal bonding through external bonding (cf. Brandal, Thorsen, \& Bratberg, 2013, p. 161). Even if Macron's pro-European socially liberal transnationalism resonates with centrist middle-class voters, the rate of abstention in the 2017 French election points to a problem with engaging the wider public.

Finally, there is the unresolved puzzle of how to slay the populist dragon and turn mistrust towards elites to positive and sustainable engagement in politics emanating on the centre-left. According to Crouch (2013, p. 167), 'A confrontation between a small arrogant elite [group] and the great majority should be attractive territory on which social democrats can fight'. Neither Macron nor Corbyn has offered a coherent agenda for 'the 99 percent' to engage in that specific confrontation. For all their differences, they have both grappled with, rather than exploited, popular discontent. In this regard, they fall in line with social democrats across the Western world who have struggled to turn a populist sentiment to their advantage (see also Meret's chapter in this volume). 


\section{References}

Akehurst, N. (2019). Why Labour must be the party of migration justice. Renewal, $27(4), 23-34$.

Anderson, P. (1994). Introduction. In P. Anderson \& P. Camiller (Eds.), Mapping the West European Left (pp. 1-22). London: Verso.

Baïetto, T., Godon, P., \& Brunn, S. (2016, October 10). Présidentielle: Revivez en intégralité le grand meeting d'Emmanuel Macron à Paris. franceinfo.

Retrieved January 31, 2019, from

https://www.francetvinfo.fr/politique/emmanuel-macron/direct-presidentielleregardez-le-grand-meeting-de-macron-a-paris_1962887.html

Baldit, E. (2017, May 2). Cambadélis annonce un nouveau PS: 'Le parti d'Épinay est mort et bien mort'. lelag.europe1.fr. Retrieved January 31, 2019, from $\mathrm{http}$ ///lelab.europe1.fr/cambadelis-annonce-un-nouveau-ps-le-parti-depinayest-mort-et-bien-mort-3317411

Barbarit, S. (2016, April 14). Emmanuel Macron met « en marche » un grand porteà-porte pour le mois de mai. Public Senat. Retrieved May 31, 2020, from https://www.publicsenat.fr/lcp/politique/emmanuel-macron-met-marche-ungrand-porte-porte-mois-mai-1313561

Bassett, L. (2019). Actually existing Corbynism. Renewal, 27(3), 37-45.

Bearce, D. (2009). Monetary divergence: Domestic policy autonomy in the postBretton Woods era. University of Michigan Press.

Benn, T. (1980). Arguments for socialism. C. Mullin (Ed.). London: Penguin.

Billard, S. (2017, January 16). Présidentielle: Pourquoi Macron et Mélenchon peuvent faire exploser le PS. L'OBS. Retrieved January 31, 2019, from https://www.nouvelobs.com/politique/election-presidentielle2017/20170116.OBS3861/presidentielle-pourquoi-macron-et-melenchonpeuvent-faire-exploser-le-ps.html

Bishop, M., \& Payne, T. (2019). The Left and the case for 'progressive reglobalisation'. Renewal, 27(3), 79-95.

Bolton, M., \& Pitts, F. H. (2018)..Corbynism: A critical approach. Bingley: Emerald.

Boudet, A. (2018, March 17). Les Jeunes avec Macron, succursale d'ex-socialistes au service de LREM, désignent leur chef. Huffington Post. Retrieved January 31, 2019, from https://www.huffingtonpost.fr/entry/les-jeunes-avec-macronsuccursale-dex-socialistes-au-service-de-lrem-designent-leurchef_fr_5c92e254e4b06b13b188c3ad

Brandal, N., Thorsen, D. E., \& Bratberg, Ø. (2013). The Nordic model of social democracy. Basingstoke: Palgrave Macmillan.

Bruckert, E. (2016, April 13). Parti socialiste: Adhésions en chute dans les fédérations. Le Parisien. Retrieved January 31, 2019, from http://www.leparisien.fr/politique/parti-socialiste-adhesions-en-chute-dans-lesfederations-13-04-2016-5710959.php

Chrisafis, A. (2013, October 29). François Hollande becomes most unpopular French president ever. The Guardian. Retrieved January 31, 2019, from 
https://www.theguardian.com/world/2013/oct/29/francois-Hollandeee-mostunpopular-president

Clift, B., \& McDaniel, S. (2017). Is this crisis of French socialism different? Hollande, the rise of Macron, and the reconfiguration of the Left in the 2017 presidential and parliamentary elections. Modern \& Contemporary France, 25(4), 403-415.

Coates, D., \& Lawler, P. (2000). New Labour in power. Manchester: Manchester University Press.

Cole, A. (2019). Emmanuel Macron and the two years that changed France. Manchester: Manchester University Press.

Crouch, C. (2013). Class politics and the social investment welfare state. In M. Keating \& D. McCrone (Eds.), The crisis of social democracy in Europe. Edinburgh: Edinburgh University Press.

Daniels, G. \& McIlroy, J. (2008). Trade unions in a neoliberal world: British trade unions under New Labour. London: Taylor \& Francis.

Davis, J., \& McWilliam, R. (2018). Introduction: New histories of Labour and the Left in the 1980s. In J. Davis \& R. McWilliam (Eds.), Labour and the Left in the 1980s (pp. 1-24). Manchester: Manchester University Press.

Dennis, J. (2020). A party within a party posing as a movement? Momentum as a movement faction. Journal of Information Technology \& Politics, 17(2), 97113.

Dorey, P., \& Denham, A. (2011). 'O brother, where art thou?' The Labour Party leadership election of 2010. British Politics, 6, 286-316.

Dølvik, J. E., Fløtten, T., Hippe, J. M., \& Jordfald, B. (2014). The Nordic model towards 2030: A new chapter? Oslo: Fafo.

Earle, S. (2017, April 24). The fall of the French left. The Atlantic. Retrieved January 31 , 2019, from

https://www.theatlantic.com/international/archive/2017/04/france-socialisthamon-macron-le-pen-melenchon-election/524085

Egle, C., Ostheim, T., \& Zohlnhöfer, R. (2013). Das rot-grüne Projekt. Eine Bilanz der Regierung Schröder 1998-2002. Springer-Verlag.

Elgie, R. (2018). The election of Emmanuel Macron and the new French party system: A return to the éternel marais? Modern \& Contemporary France, 26(1), 15-29.

Elman, C. (2009). Explanatory typologies in qualitative analysis. In D. Byrne \& C. C. Ragin (Eds.), The SAGE handbook of case-study methods. London: SAGE.

Evans, J., \& Ivaldi, G. (2018). The 2017 French presidential elections: A political reformation? Basingstoke: Palgrave Macmillan.

Freyssenet, E. (2014, April 1). Manuel Valls, social-libéral tendance 'patriote'. Les Echos. Retrieved January 31, 2019, from https://www.lesechos.fr/2014/04/manuel-valls-social-liberal-tendancepatriote-299956 
Gamble, A., \& Wright, T. (1999). Introduction: The new social democracy. In A. Gamble \& T. Wright (Eds.), The new social democracy. Oxford: Blackwell.

Garland, J. (2017). Labour's new model party. In M. Perryman (Ed.), The Corbyn effect. London: Lawrence and Wishart.

Giddens, A. (1998). The third way: The renewal of social democracy. Cambridge: Polity Press.

Gilbert, J. (2018, January 14). The Bennites' revenge: How Jeremy Corbyn and his allies survived political exile. New Statesman. Retrieved January 31, 2019, from https://www.newstatesman.com/politics/uk/2018/01/bennites-revengehow-jeremy-corbyn-and-his-allies-survived-political-exile

Goes, E. (2016). The Labour Party under Ed Miliband. Trying but failing to renew social democracy. Manchester: Manchester University Press.

Goodwin, M. (2018, November 20). How Corbynomics is winning over Britain. UnHerd. Retrieved January 31, 2019, from https://unherd.com/2018/11/corbynomics-winning-britain/?=refinnar

Guinan, J., \& Hanna, T. M. (2018). Democratic ownership in the new economy. In J. McDonnell (Ed.), Economics for the many. London: Verso.

Hannah, S. (2018). A party with Socialists in it: A history of the Labour Left. London: Pluto Press.

Hattersley, R. (2004, May 10). We should have made it clear that we too were modernisers. New Statesman. Retrieved January 31, 2019, from https://www.newstatesman.com/node/159728

Heffernan, R. (2001). New Labour and Thatcherism: Political change in Britain. Basingstoke: Palgrave Macmillan.

Hewlett, N. (2017). The phantom revolution. The presidential and parliamentary elections of 2017. Modern \& Contemporary France, 25(4), 377-390.

Jenkins, R. (1952). Equality. In R. Crossman (Ed.), New fabian essays (pp. 69-90). London: Turnstile Press.

Journal Officiel. (2016). Journal Officiel de la Républic Française. Lois et décrets, annonce no. 1506 - page 91. Déclaration à la préfecture de police, La Gauche Libre. http://www.journalofficiel.gouv.fr/publications/assoc/pdf/2016/0011/JOAFE_PDF_Unitaire_201 60011_01506.pdf.

Kauffmann, S. (2020, May 22). Can Europe stay back from the brink? The New York Times. Retrieved May 31, 2020, from https://www.nytimes.com/2020/05/22/opinion/europe-back-frombrink.html?action $=$ click \&module $=$ Opinion \&pgtype $=$ Homepage

Keating, M., \& McCrone, D. (2013). The crisis of social democracy. In M. Keating \& D. McCrone (Eds.), The crisis of social democracy in Europe. Edinburgh: Edinburgh University Press.

Le Figaro. (2008, November 7). Jean-Luc Mélenchon quitte le PS. Le Figaro. Retrieved January 31, 2019, from https://www.lefigaro.fr/flash- 
actu/2008/11/07/01011-20081107FILWWW00341-jean-luc-melenchonquitte-le-ps.php

Le Parisien. (2008a, November 29). Le parti de Mélenchon réunit un millier de sympathisants. Le Parisien. Retrieved January 31, 2019, from http://www.leparisien.fr/politique/le-parti-de-melenchon-reunit-un-millier-desympathisants-29-11-2008-326704.php

Le Parisien. (2008b, November 2). La social-démocratie est un modèle périmé. Le Parisien. Retrieved January 31, 2019, from http://www.leparisien.fr/politique/royal-la-social-democratie-est-un-modeleperime-02-11-2008-296818.php

L'Express. (2018, March 17). Les 'Jeunes avec Macron' changent de tête sous le patronage du gouvernement. Retrieved January 31, 2019, from https://www.lexpress.fr/actualites/1/societe/les-jeunes-avec-macron-changentde-tete-sous-le-patronage-du-gouvernement_1993189.html

Macron, E. (2017). Revolution. København: Informations forlag.

Manwaring, R., \& Smith, E. (2019). Corbyn, British Labour and policy change. British Politics, 15(1), 25-47.

Mihaely, G. (2017, April 26). Gauche en phase terminale. Causeur.fr. Retrieved January 31, 2019, from https://www.causeur.fr/gauche-echec-hamonmelenchon-macron-143960\#

Moschonas, G. (2002). In the name of social democracy. The great transformation: 1945 to the present. London: Verso.

Noyon, R. (2016, November 21). Comment Emmanuel Macron fait-il son 'diagnostic'? Indice: Il a besoin de linguistes. L'OBS. Retrieved May 31, 2020, from https://www.nouvelobs.com/rue89/rue89politique/20161116.RUE3756/comment-emmanuel-macron-a-fait-sondiagnostic.html

Pedder, S. (2018, June 8). Emmanuel Macron is neither Margaret Thatcher nor Tony Blair. Financial Times. Retrieved January 31, 2019, from https://www.ft.com/content/22165716-698e-11e8-aee1-39f3459514fd

Rathgeb, P., \& Wolkenstein, F. (2017, June 10). Macron as saviour of social democracy? The third way à la Française. Democratic Audit. Retrieved January 31, 2019, from http://www.democraticaudit.com/2017/07/10/macronas-saviour-of-social-democracy-the-third-way-a-la-francaise

Raulin, N. (2016). 'En marche': Le bébé du ministre fait ses premiers pas. Liberation. Retrieved January 31, 2019, from https://www.liberation.fr/france/2016/04/20/en-marche-le-bebe-du-ministrefait-ses-premiers-pas_1447557

Raymond, G. (2017). Beyond Left and Right? Modern \& Contemporary France, 25(4), 417-428.

Royal, F. (2020). The Gilets Jaunes protests: Mobilisation without Third-Party support. Modern \& Contemporary France, 28(1), 99-118.

Sage, A. (2020, January 14). Palace politics: Macron gambles that his future lies on the right. The Times. Retrieved January 31, 2020, from 
https://www.thetimes.co.uk/article/palace-politics-macron-gambles-that-hisfuture-lies-on-the-right-q2nxj8927

Salvi, E. (2018, January 15). Aux sources du Macronisme. Mediapart. Retrieved January 31, 2019, from https://www.mediapart.fr/journal/france/150118/auxsources-du-macronisme?onglet=full

Scarrow, S. E. (2019). Multi-speed parties and representation: the evolution of party affiliation in Germany. German Politics, 28(2), 162-182.

Schattle, H. (2018). Globalisation, the breaking and remaking of social democratic citizenship. In H. Schattle \& J. Nuttall (Eds.), Making Social Democrats. citizens, mindsets, realities: Essays for David Marquand. Basingstoke: Palgrave Macmillan.

Shenker, J. (2019, November 8). Why Corbynism matters. Prospect. Retrieved November 9, 2019, from https://www.prospectmagazine.co.uk/politics/whatis-corbynism-meaning-jack-shenker

Stafford, J., \& Sutcliffe-Braithwaite F. (2017). Ready for government? Renewal, $25(3-4), 6-15$.

TF1News. (2011, May 23). C'est quoi 'un président normal'? TF1News. Retrieved January 31, 2019, from http://lci.tf1.fr/politique/c-est-quoi-un-presidentnormal-6499482.html

Volpicelli, G. (2019, December 4). The UK could be on the verge of a major universal basic income trial. Wired. Retrieved January 12, 2020, https://www.wired.co.uk/article/uk-universal-basic-income-experiment

Whiteley, P., Poletti, M., Webb, P., \& Bale, T. (2019). Oh Jeremy Corbyn! Why did Labour Party membership soar after the 2015 general election? The British Journal of Politics and International Relations, 21(1), 80-98.

Wolfrum, E. (2013). Rot-Grün an der Macht. Deutschland 1998-2005. Munich: C.H. Beck Verlag.

Worth, O. (2019). The new left, Jeremy Corbyn and the war of position: A new coherence or further fragmentation? Globalizations, 16(4), 489-502.

Wright, T. (2018). Democracy and social democracy. In H. Schattle \& J. Nuttall (Eds.), Making Social Democrats. citizens, mindsets, realities: Essays for David Marquand. Basingstoke: Palgrave Macmillan. 


\section{Tables and figures - Brandal \& Bratberg}

Table 1. Two trajectories for renewing the Left in post-austerity Europe

\begin{tabular}{|l|l|l|l|l|}
\hline & In government & $\begin{array}{l}\text { Failures as } \\
\text { internally } \\
\text { perceived }\end{array}$ & $\begin{array}{l}\text { Primary reference } \\
\text { point for catharsis }\end{array}$ & $\begin{array}{l}\text { Outcome/first } \\
\text { mover }\end{array}$ \\
\hline $\begin{array}{l}\text { Parti } \\
\text { Socialiste }\end{array}$ & Yes & $\begin{array}{l}\text { Elitism, an } \\
\text { insufficient } \\
\text { narrative and } \\
\text { governing } \\
\text { incompetence }\end{array}$ & $\begin{array}{l}\text { Mitterrand (social } \\
\text { cohesion and } \\
\text { European destiny, } \\
\text { democratic reforms } \\
\text { and flexibility } \\
\text { regarding economic } \\
\text { policy) }\end{array}$ & $\begin{array}{l}\text { Macronism => } \\
\text { liberal centre }\end{array}$ \\
\hline Labour & No & $\begin{array}{l}\text { Elitism and } \\
\text { betrayal of the } \\
\text { working class } \\
\text { and an } \\
\text { insufficient } \\
\text { narrative }\end{array}$ & $\begin{array}{l}\text { (collectivism, } \\
\text { redistribution, } \\
\text { public ownership } \\
\text { and social justice } \\
\text { through the state } \\
\text { apparatus) }\end{array}$ & $\begin{array}{l}\text { Old Left } \\
\text { authenticity }\end{array}$ \\
\hline
\end{tabular}

